\title{
Numerical Analysis of Crack Progress in Different Areas of a Friction Stir Welded Bead for an 5251 H14 Aluminum Alloy Specimen
}

\author{
Youb Kambouz \\ University of Sidi Bel-Abbes \\ Materials and Reactive Systems \\ Laboratory \\ y.kambouz@yahoo.fr
}

\author{
Mohamed Benguediab \\ University of Sidi Bel-Abbes \\ Materials and Reactive Systems \\ Laboratory \\ benguediab_m@yahoo.fr
}

\author{
Benattou Bouchouicha \\ University of Sidi Bel-Abbes \\ Materials and Reactive Systems \\ Laboratory \\ benattou_b@yahoo.fr
}

\begin{abstract}
The assemblies welded by Friction Stir Welding have a major advantage which is the absence of a metal filler. This process contributes to the welding of materials that are known to be difficult to weld using the conventional techniques often employed in the field of transport, for example in the automobile body by applying a spot welding. The numerical modeling of this type of process is complex, not only in terms of the variety of physical phenomena which must be considered, but also because of the experimental procedure that must be followed in order to verify and validate numerical predictions. In this work, a finite element model is proposed in order to simulate the crack propagation under monotonic loading in different areas of the weld seam of a strain hardening CT-50 aluminum alloy 5251H14 specimen.
\end{abstract}

Keywords- FSW; micro hardness; 5251 H14 aluminum alloy; crack; stress intensity factor

\section{INTRODUCTION}

Considered as the most significant development in metal joining in the last decade, the Friction Stir Welding (FSW) is a joining process with good energy efficiency that is also environmentally friendly and versatile. Significant research has been conducted in various fields since the invention of this technique in 1991 [1].

Generally, FSW specimens have higher resistance than specimens welded using the Metal Inert Gas (MIG) and Tungsten Inert Gas (TIG) processes [2-6]. Ericson and Sandstrom [2] compared fatigue results of friction stir welds with data obtained for conventional arc-welding methods, namely, MIG-pulse and TIG processes in aluminum alloy (T6 and T4 conditions). Moreira et al. [3,4] also compared the fatigue behaviour of joints performed by the traditional MIG welding process and by the FSW process, observing that FSW and MIG welded specimens had lower yield and ultimate stresses than the base material. In general, a higher lifetime for the friction stir welds in comparison with other welds was also observed [5]. It has also been observed that FSW leads to a decline of the mechanical properties of weld bead in comparison to the base metal [6]. Furthermore, an important hardness decrease in the ThermoMechanically Affected Zone (TMAZ) and the nugget zone average hardness was found. Due to severely thermal and mechanical deformation in the weld zone during FSW, the weld zone generally possesses various microstructural features and various mechanical properties [78]. The crack propagation in the weld bead (FSW and classic) is known to be concerned by residual stress and/or hardness around the welded zone [9, 10]. Cecile Genevois [11] conducted hardness tests on micro-specimen. The limit of elasticity, tensile strength and Young's modulus (E) of the aluminum alloy were measured using tensile tests on welded and non-welded specimens. Modeling the tensile behavior of welded FSW for an aluminum alloy joint showed that the weak area is the TMAZ [12]. Welding parameters also affect the mechanical properties of the weld and its resistance is related to the speed of rotation of the welding tool $[13,14]$. It is therefore advisable to choose the best parameters (speed, welding speed and good fixation of the parts) [15].

The overall objective of this work is to study using finite element (FE) analysis the effects of loading on crack propagation in different areas of FSW in the case of a 5251 aluminum alloy subjected to $\mathrm{H} 14$ treatment. In the numerical approach the stress intensity factor is determined by the finite element method using the ABAQUS software.

\section{PRESENTATION OF THE MATERIAL}

The material used is an aluminum alloy 5000 series subjected to H14 treatment (deformed 25\%), which will help the investigation of the various phenomena that occur during welding without involving the precipitation phenomenon.

\section{A. Mechanical properties of the material.}

The chemical and mechanical properties are given in Tables I and II.

TABLE I. CHEMICAL COMPOSITION OF THE ALUMINUM ALLOY 5251

\begin{tabular}{|c|c|c|c|c|c|c|c|c|}
\hline $\mathrm{Si}$ & $\mathrm{Fe}$ & $\mathrm{Cu}$ & $\mathrm{Mn}$ & $\mathrm{Mg}$ & $\mathrm{Cr}$ & $\mathrm{Zn}$ & $\mathrm{Ti}$ & $\mathrm{Al}$ \\
\hline 0.4 & 0.5 & 0.15 & 0.10 & 1.72. & 0.15 & 0.15 & 0.15 & remains \\
\hline
\end{tabular}


TABLE II. MECHANICAL PROPERTIES OF 5251

\begin{tabular}{|c|c|c|c|c|c|c|}
\hline Nuance & $\begin{array}{c}\text { metallurgic } \\
\text { state }\end{array}$ & $\begin{array}{c}\mathrm{R}_{\mathrm{m}} \\
{[\mathrm{MPa}]}\end{array}$ & $\begin{array}{c}\mathrm{R}_{\mathrm{p}} \\
{[\mathrm{MPa}]}\end{array}$ & $\begin{array}{c}\mathrm{A} \\
\%\end{array}$ & $\begin{array}{c}\mathrm{E} \\
{[\mathrm{MPa}]}\end{array}$ & $\mathrm{H}_{\mathrm{v}}$ \\
\hline $5251\left[\mathrm{Al}^{\left.-\mathrm{Mg}_{2}\right]}\right.$ & $\mathrm{H} 14$ & 210 & 170 & $3-5$ & 70000 & $82-84$ \\
\hline
\end{tabular}

B. Hardness profile.

The optimization of the weld process requires the mechanical characterization of the weld bead. The most commonly used practice is the measurement of microhardness which gives a first evaluation of the mechanical properties in different areas of the weld, in order to obtain a profile across it and to establish the weld zones. The cross-section thus provides a profile of microhardness [11]. Pictures of the microstructure of the different areas of the $5251 \mathrm{H} 14$ alloy aluminum can be found in [8].

\section{MODEL USED}

\section{A. Modeling of the cracked part}

The modeled weld is divided into several zones, as shown in Figure 1, and a different mechanical behavior is assigned for each. The mechanical properties described in [11] are used.

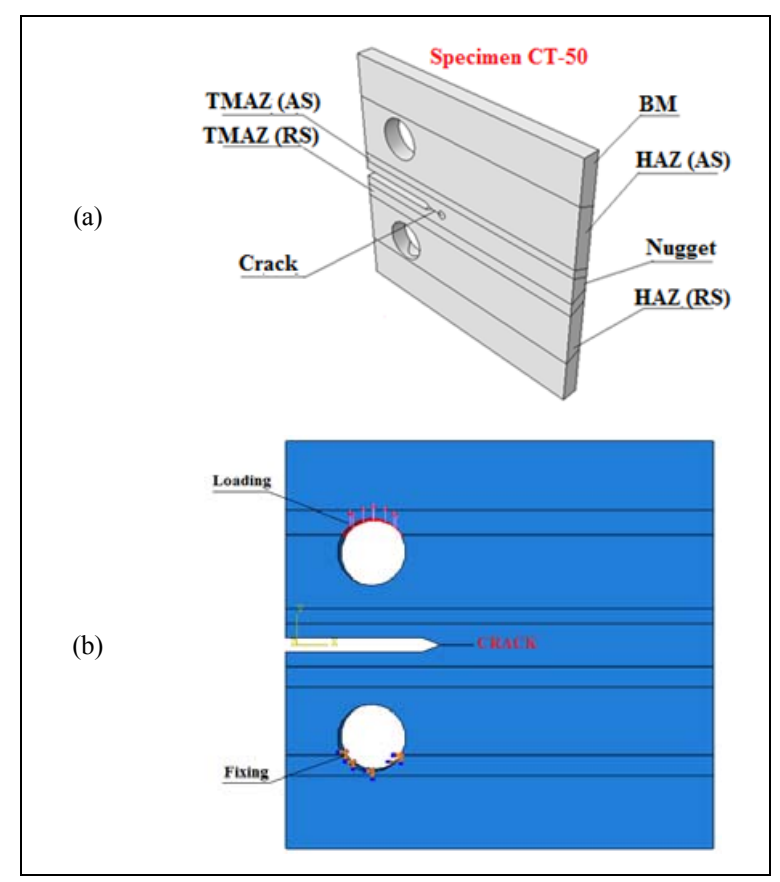

Fig. 1. Geometrical representation by ABAQUS of notched specimen «CT-50». a) Representation of welding areas b) Loading and fixing of the specimen

In the model considered in this paper, the areas are fully supportive of each other, movement is continuous and normal stress is transmitted. This model allows the obtainment of a mapping of local deformations through a welded joint subjected to a uniaxial load $\mathrm{P}=40 \mathrm{MPa}$ (Figure $1 \mathrm{~b}$ ). The part is considered as a CT-50 specimen, the cracking plane is considered normal to the loading axis and the crack front is considered straight.

\section{B. Mesh of the cracked part}

The numerical analysis of the mechanical fields of a cracked part is strongly linked to the meshing quality of this part, particularly the vicinity of the crack tip. It is therefore important to manage the mesh to the crack tip (Figure 2).

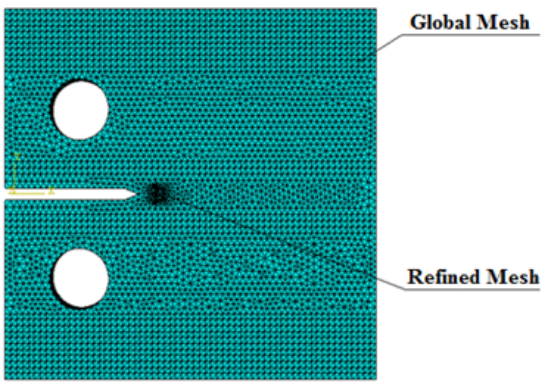

Fig. 2. Mesh of the specimen

\section{NUMERICAL RESULTS AND DISCUSSIONS}

\section{A. Determination of the stress intensity factor on the crack front.}

Crack propagation is a complex problem, depending on various factors such as the nature of the applied load, the level of residual stress, the geometry of the part etc. The kinetics of cracking along the crack front can be very diverse, leading to highly variable shapes of the crack front. As a result, the observation of crack propagation on the surface of the part is not enough to predict the propagation route. Therefore it is important to predict the evolution of the crack front during the propagation. Many authors use the following procedure to model the evolution of the crack front under monotonic loading or fatigue. At any edge, the stress intensity factor $\mathrm{K}$ is determined along the crack front. Advanced $\Delta \mathrm{a}$ is then attributed to the crack "a" to evaluate new values of $\mathrm{K}$. This is repeated for different values of $\mathrm{K}$ in order to draw $\mathrm{K}$ curves on the length of the crack front for different areas of the weld (Figure 3).

It may be noted from Figure 3 that for a given crack length $\mathrm{a}=15 \mathrm{~mm}$, the minimal stress intensity factor (in the TMAZ) is $\mathrm{K}_{\mathrm{Il}}=14.08 \mathrm{MPa} \cdot \mathrm{m}^{1 / 2}$. In the middle of the crack front (Figure 4), against the surface (face of the crack) a $K_{I 2}=11.88 \mathrm{MPa}^{1 /}$ 2 is recorded. In the HAZ, in the middle of the crack front, $\mathrm{K}_{\mathrm{I} 1}=17.60 \mathrm{MPa} \mathrm{m}{ }^{1 / 2}$ and at the surface $\mathrm{K}_{\mathrm{I} 2}=13.75 \mathrm{MPa} \mathrm{m}^{1 / 2}$. In the nugget $\mathrm{K}_{\mathrm{Il}}=19.15 \mathrm{MPa} \mathrm{m}^{1 / 2}$ and $\mathrm{K}_{\mathrm{I} 2}=17 \mathrm{MPa} \mathrm{m}^{1 / 2}$. In the base metal, $\mathrm{K}_{\mathrm{Il}}=21.50 \mathrm{MPa} \mathrm{m}^{1 / 2}$ and $\mathrm{K}_{\mathrm{I} 2}=18.75 \mathrm{MPa}^{\mathrm{i} / 2}$.

These curves (in different zones of the weld), also show that the evolution of the stress intensity factor is not straight along the crack front, but it tends to take a parabolic shape and that the minimum value of $\mathrm{K}$ is found at the surface (on the face of the crack) whereas the maximum is found at the heart (middle of the crack front). Based on the values of the stress intensity factor $\mathrm{K}$ recorded in Table II it can be said that for the same advanced crack $(\mathrm{a}=15 \mathrm{~mm})$, minimum and maximum values are recorded in the base metal then nugget, the HAZ and finally TMAZ. 


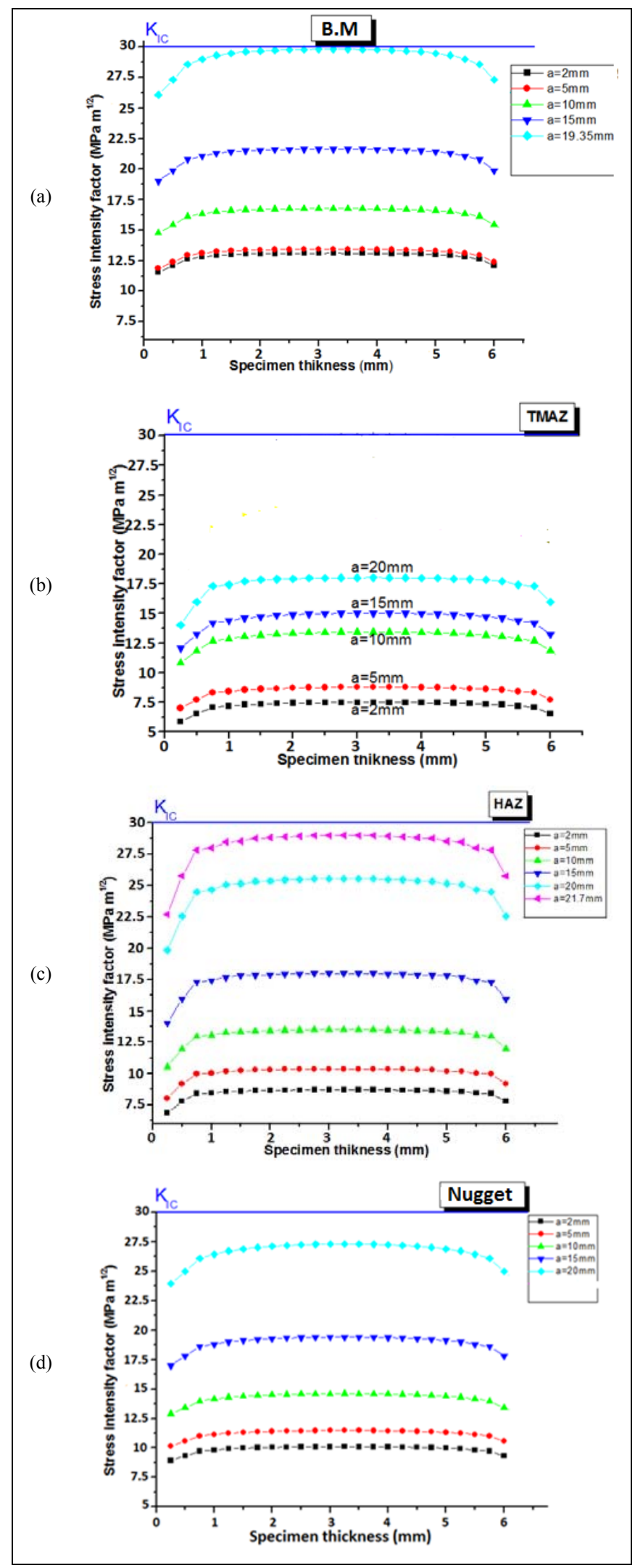

Fig. 3. Variation of stress intensity factor $\mathrm{K}$ in a) BM, b) TMAZ, c) HAZ, d) Nugget.

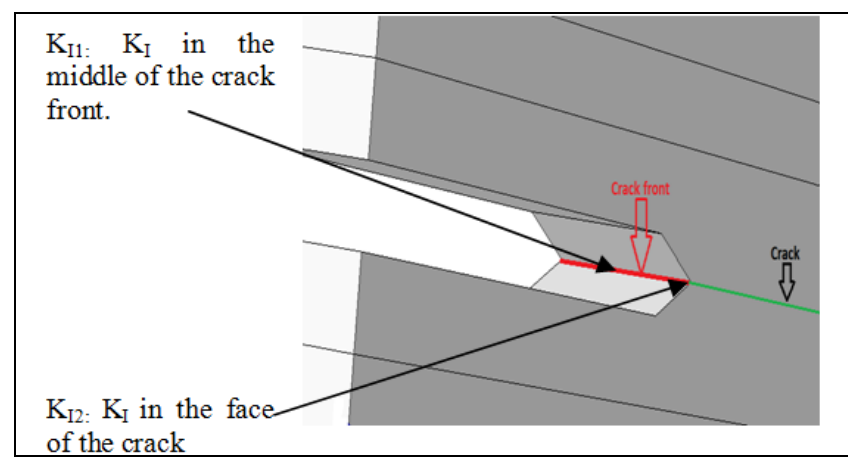

Fig. 4. Representation of the front and crack length "a"

TABLE III. MINIMUM AND MAXIMUM VALUES IN THE AREAS OF FSW

\begin{tabular}{|c|c|c|c|c|}
\hline & TMAZ & HAZ & Nugget & B. metal \\
\hline $\begin{array}{c}\mathrm{K}_{\min } \\
\mathrm{MPa} \mathrm{m}^{1 / 2}\end{array}$ & 11.88 & 13.75 & 17.00 & 18.75 \\
\hline $\begin{array}{c}\mathrm{K}_{\max } \\
\mathrm{MPa} \mathrm{m}^{1 / 2}\end{array}$ & 14.08 & 17.60 & 19.15 & 21.50 \\
\hline
\end{tabular}

B. Determination of stress intensity factor according on the progress of crack.

From the previous results the $\mathrm{K}=\mathrm{f}(\mathrm{a})$ curves for each area of the weld are plotted as shown in Figure 5. These curves represent the change of the stress intensity factor depending on the evolution of the cracks. KI1 is the stress intensity factor in the middle of the crack front (Figure 6). KI2 is the stress intensity factor of the plane of the crack face (surface).

Table IV shows the evolution of the crack in different areas of the weld seam for the $5251 \mathrm{H} 14$ alloy. As shown, the crack starts in the affected TMAZ area that is equal to $2 \mathrm{~mm}$ for $\mathrm{K}_{\mathrm{I}}=6.75 \mathrm{MPa} \cdot \mathrm{m}^{1 / 2}$, then it continues to move forward without a declaration of crack in other areas until the value of $\mathrm{K}_{\mathrm{I}}=10$ MPa. $\mathrm{m}^{1 / 2}$. Recording is equal to a crack in the HAZ $1.85 \mathrm{~mm}$ and $5.12 \mathrm{~mm}$ in the core against the TMAZ $8.25 \mathrm{~mm}$. The TMAZ is the weakest area, and gradually as one approaches the nugget, the restoration and recrystallization are more advanced. Therefore, the yield decreases sharply while the elongation increases [8]. Recrystallization which is thin in the core enables an increase of the mechanical strength and the yield strength in this area compared to the TMAZ.

\section{Consequences of friction stir welding}

Resistance to rupture in TMAZ is equal to the yield strength of the base metal [8]. Therefore when there is a rupture in the TMAZ, the base metal is just beginning to deform plastically. These results are the consequences of FSW.

D. Analysis of the state of stresses and strains near the crack tip.

A stress field and a strain field in the material adjacent to the border are associated to each movements of the crack surfaces. The calculations were made in ABAQUS by varying the crack length as $a=2,3, \ldots, 15 \mathrm{~mm}$, and in each case the fields of stresses and strains near the crack tip for different areas of the weld were determined. 
(a)

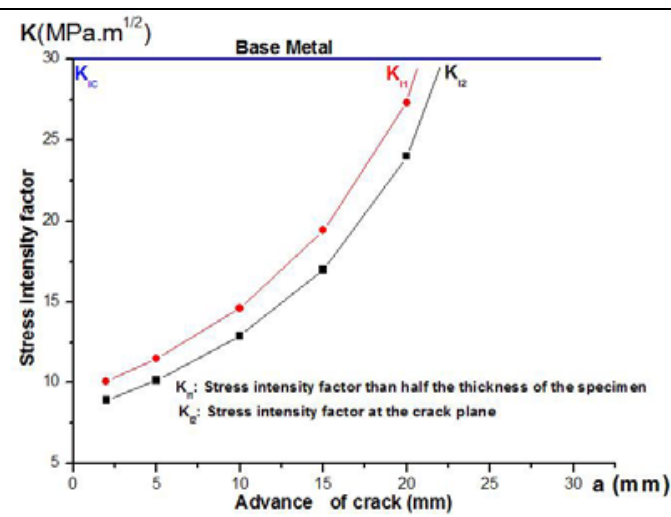

(b)

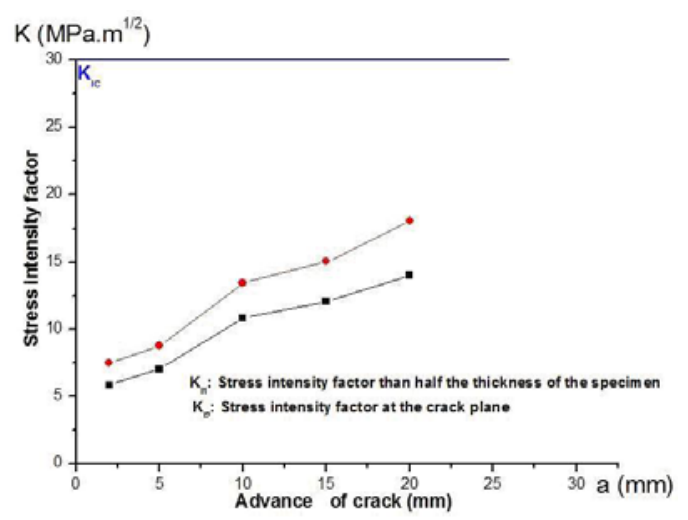

(c)

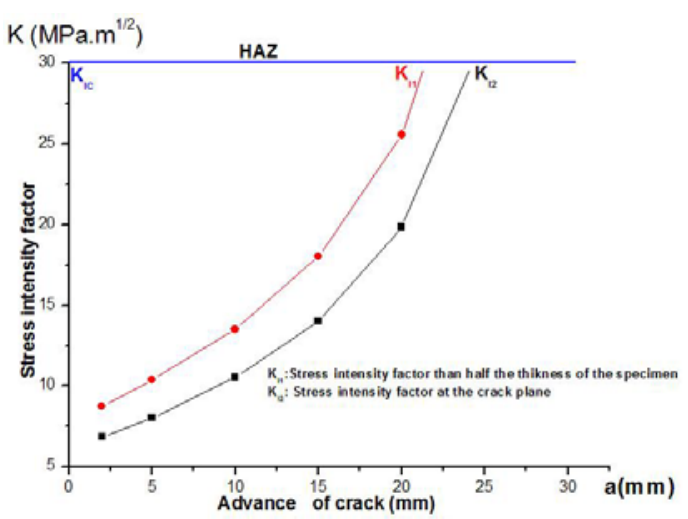

(d)

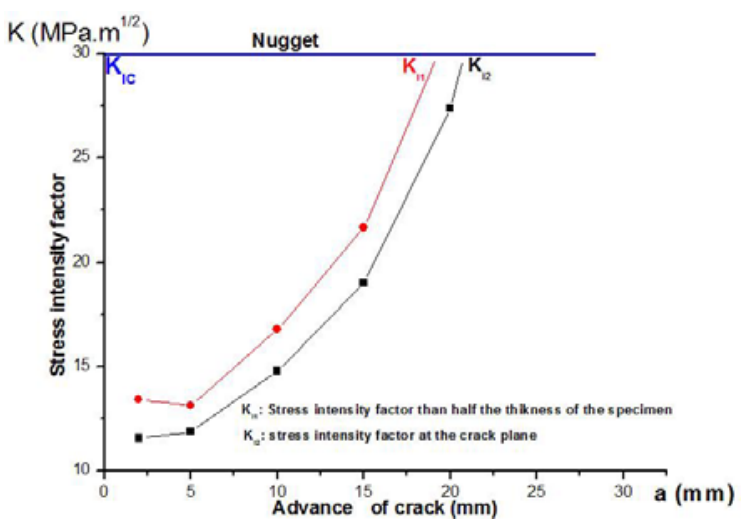

Fig. 5. Variation of stress intensity factor ( $\max$ and $\min$ ) depending on the progress of the crack in the different zones of the weld. (a) B.M. (b) TMAZ

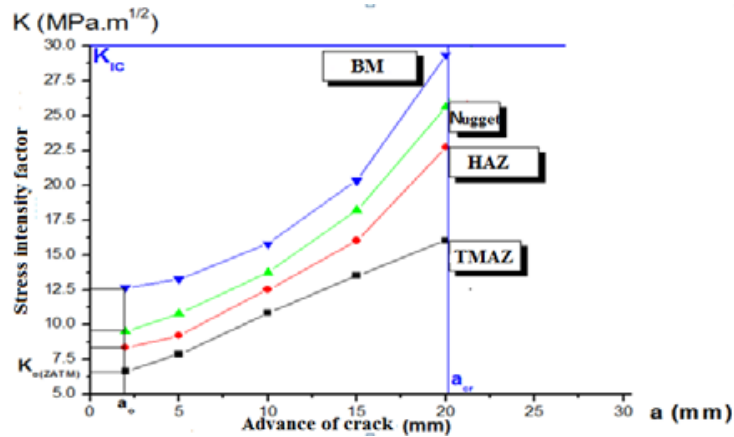

Fig. 6. Stress intensity factors K means according to the progress of the crack to the different zones of the weld bead.

TABLE IV. VARIATION OF THE STRESS INTENSITY FACTOR ACCORDING TO THE EVOLUTION OF THE CRACK

\begin{tabular}{|c|c|c|c|c|}
\hline & $\begin{array}{l}\text { a (Base } \\
\text { metal) } \mathrm{mm}\end{array}$ & $\begin{array}{l}\mathrm{a} \text { (Nugget) } \\
\mathrm{mm}\end{array}$ & $\begin{array}{l}\mathrm{a}(\mathrm{HAZ}) \\
\mathrm{mm}\end{array}$ & $\begin{array}{l}\mathrm{a} \text { (TMAZ) } \\
\mathrm{mm}\end{array}$ \\
\hline $\mathrm{K}_{\mathrm{I}}=30 \mathrm{MPa} \mathrm{m}^{1 / 2}$ & 20 & 21.3 & 23 & $\begin{array}{c}\text { Specimen } \\
\text { failure }\end{array}$ \\
\hline $\mathrm{K}_{\mathrm{I}}=25 \mathrm{MPa} \mathrm{m}^{1 / 2}$ & 16 & 18.5 & 21.5 & $\begin{array}{c}\text { Specimen } \\
\text { failure }\end{array}$ \\
\hline $\mathrm{K}_{\mathrm{I}}=20 \mathrm{MPa} \mathrm{m}^{1 / 2}$ & 14 & 16.5 & 18 & $\begin{array}{c}\text { Specimen } \\
\text { failure }\end{array}$ \\
\hline $\mathrm{K}_{\mathrm{I}}=15 \mathrm{MPa} \mathrm{m}^{1 / 2}$ & 9.9 & 11.5 & 13.75 & 19.50 \\
\hline $\mathrm{K}_{\mathrm{I}}=10 \mathrm{MPa} \mathrm{m}^{1 / 2}$ & $\begin{array}{c}\text { no crack } \\
\text { initiation }\end{array}$ & 1.85 & 5.12 & 8.25 \\
\hline $\mathrm{K}_{\mathrm{I}}=7.5 \mathrm{MPa} \mathrm{m}^{1 / 2}$ & $\begin{array}{c}\text { no crack } \\
\text { initiation }\end{array}$ & $\begin{array}{c}\text { no crack } \\
\text { initiation }\end{array}$ & $\begin{array}{c}\text { no crack } \\
\text { initiation }\end{array}$ & 2.65 \\
\hline $\mathrm{K}_{\mathrm{I}}=6.75 \mathrm{MPam}^{1 / 2}$ & $\begin{array}{c}\text { no crack } \\
\text { initiation }\end{array}$ & $\begin{array}{c}\text { no crack } \\
\text { initiation }\end{array}$ & $\begin{array}{c}\text { no crack } \\
\text { initiation }\end{array}$ & 2 \\
\hline
\end{tabular}
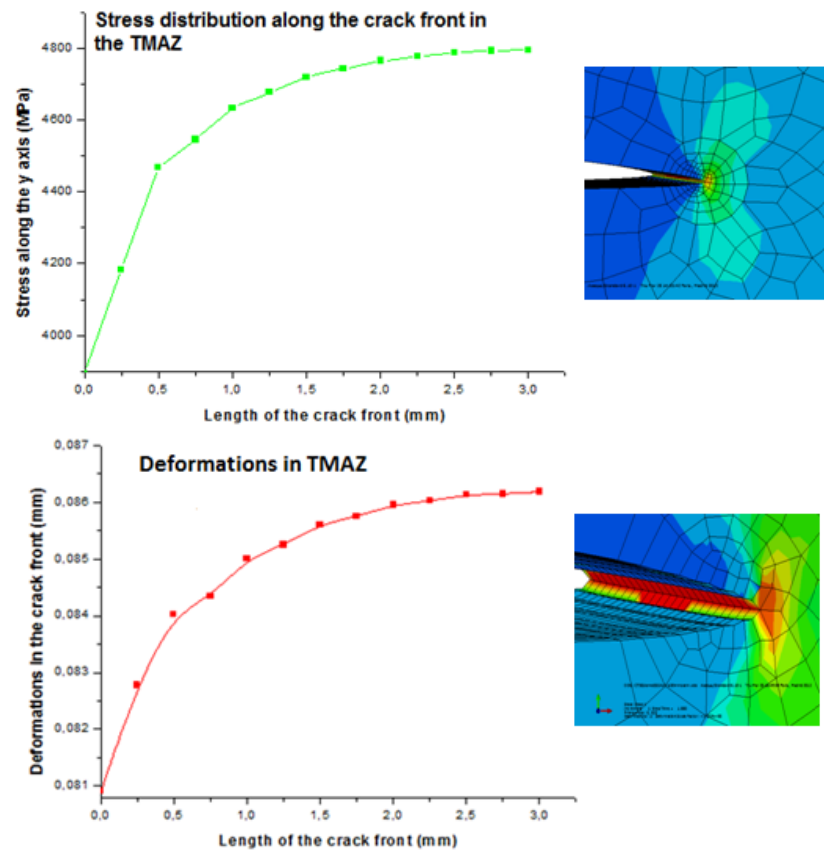

Fig. 7. Distribution of stresses $\sigma_{y y}$ and deformations $\varepsilon_{y y}$ on the crack front (in TMAZ) for $\mathrm{a}=15 \mathrm{~mm}$ (c) HAZ (d) Nugget 

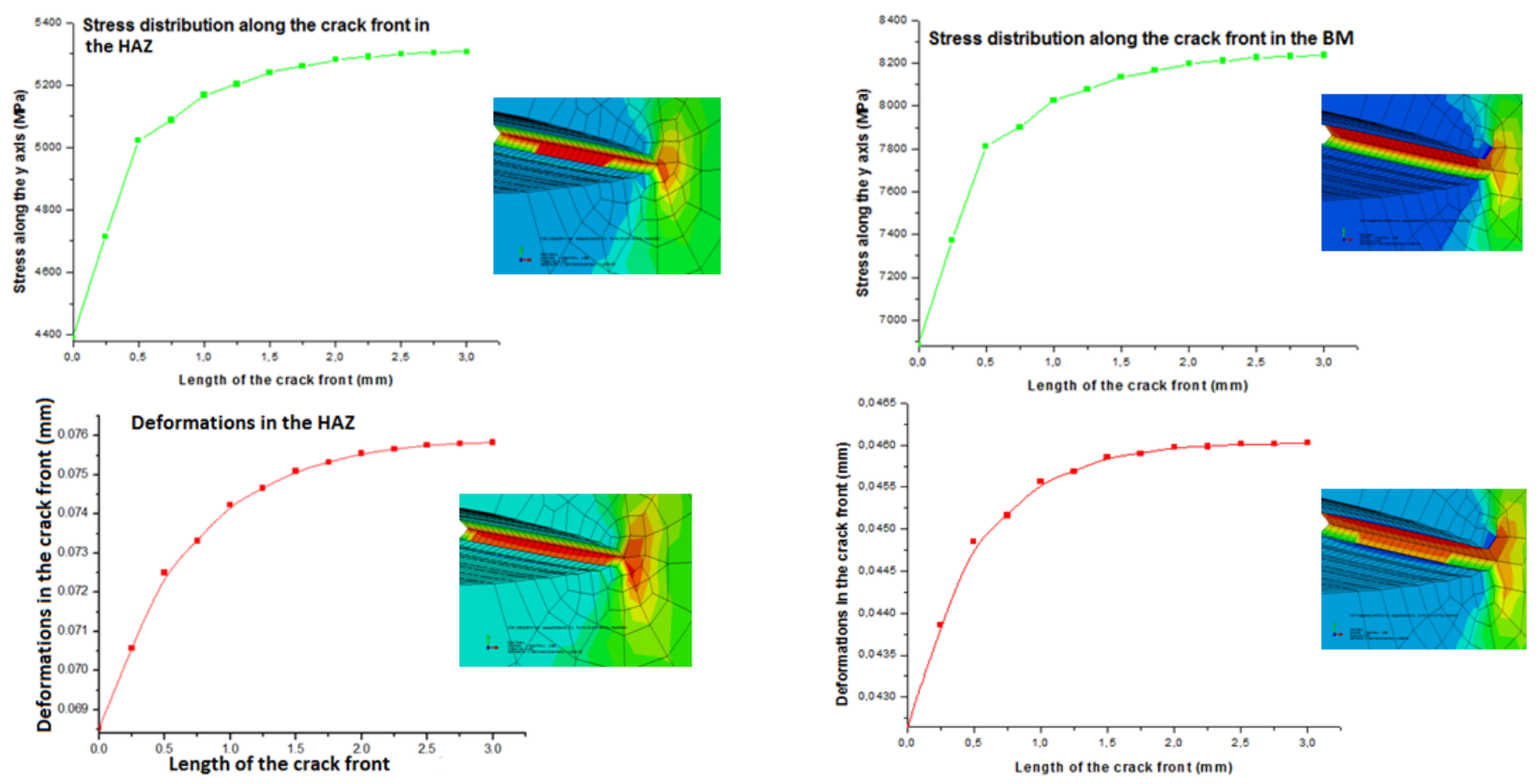

Fig. 8. Distribution of stresses $\sigma_{y y}$ and deformations $\varepsilon_{y y}$ on the crack front (in the HAZ) for $\mathrm{a}=15 \mathrm{~mm}$
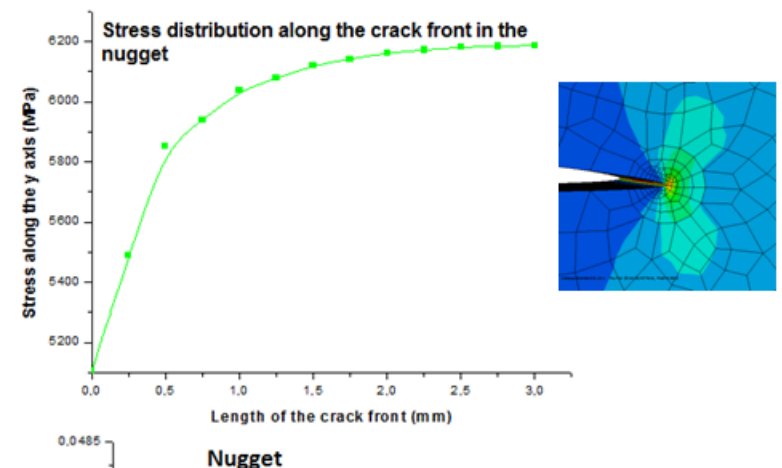

Fig. 10. Distribution of stresses $\sigma_{y y}$ and deformations $\varepsilon_{y y}$ on the crack front (in the base metal) for $\mathrm{a}=15 \mathrm{~mm}$.

Figures 7-10 allow us to ensure that the maximum deformations along the crack front are the most important in the TMAZ, HAZ then the Nugget and finally the Base metal. In the base metal which is harder than the TMAZ (about 1.7 times), the maximum stress recorded are shown in Table V. It should also be noted that the highest deformation is recorded in the TMAZ, compared with other regions, although the $y y$ stresses are low (should be attributed to the softer material of the TMAZ).

\section{CONCLUSION}

This article focuses on the study of the evolution of cracks in different areas of a friction stir welding under monotonic loading and of the variation of the stress intensity factor and of the distribution of stress and strain on the crack tip in the different zones of the weld bead. A preliminary study was done to show that the crack does not evolve in the same way in the middle of the crack front and on her face. The second part of this paper is devoted to the determination of the stress intensity factor as a function of the evolution of the crack. The last part shows the distribution of stress and strain on the crack tip in the different zones of the weld bead. Modeling and simulation were performed using the ABAQUS software and results are depicted through various figures, and further discussed.

\section{REFERENCES}

TABLE V. MAXIMUM STRESSES AND DEFORMATIONS ALONG THE CRACK FRONT IN DIFFERENT AREAS OF THE FSW.

\begin{tabular}{|c|c|c|c|c|}
\hline & TMAZ & HAZ & Nugget & BM \\
\hline $\begin{array}{c}\text { Stresses } \boldsymbol{\sigma}_{\boldsymbol{y} y} \\
(\mathbf{M P a})\end{array}$ & 4800 & 5287 & 6200 & 8200 \\
\hline $\begin{array}{c}\text { Deformations } \\
\mathbf{E}_{22}(\mathbf{m m})\end{array}$ & 0.086 & 0.076 & 0.0485 & 0.0465 \\
\hline
\end{tabular}

[1] W. M. Thomas, E. D. Nicholas, J. C. Needham, M. G. Murch, P Temple-Smith P, C. J. Dawes, "Friction-stir butt weldin", G.B. Patent No. 9125978.8, International patent application No. PCT/GB92/02203, 1991

[2] M. Ericsson, R. Sandstrom, "Influence of welding speed on the fatigue of friction stir welds and comparison with MIG and TIG", International Journal of Fatigue, Vol. 25, No. 12, pp. 1379-1387, 2003 
[3] P. M. G. P. Moreira, A. M. P. de Jesus, A. S. Ribeiro, P. M. S. T. de Castro, "Assessment of the fatigue behaviour of friction stir welded joints: aluminum alloy 6082-T6", Key Engineering Materials, Vol. 348-349, pp. 209-212, 2007

[4] P. M. G. P. Moreira, A. M. P. de Jesus, A. S. Ribeiro, . M. S. T. de Castro, "Fatigue crack growth in friction stir welds of 6082-T6 and 6061-T6 aluminium alloys: a comparison, “, Theoretical and Applied Fracture Mechanics, Vol. 50, No. 2, pp. 81-91, 2008

[5] Y. Kobayashi, M. Sakuma, Y. Tanaka, K. Matsuoka, "Fatigue strength of friction stir welding joints of aluminium alloy 6082 extruded shape", Welding International, Vol. 21, No. 1, pp. 18-24, 2007

[6] J. D. Costa, J. A. M. Ferreira, L. P. Borrego, "Influence of spectrum loading on fatigue resistance of AA6082 friction stir welds", International Journal of Structural Integrity, Vol. 2, No. 2, pp. 122-134, 2011

[7] K. V. Jata, K. K. Sankaran, J. J. Ruschau, "Friction-stir welding effects on microstructure and fatigue of aluminum alloy 7050-T7451", Metallurgical and Materials Transactions A, Vol. 31, No. 9, pp. 21812192, 2000

[8] A. L. Etter, T. Baudin, N. Fredj, R. Penelle, "Recrystallization mechanisms in $5251 \mathrm{H} 14$ and $5251 \mathrm{O}$ aluminum friction stir welds", Materials Science and Engineering: A, Vol. 445-446, pp. 94-99, 2007

[9] G. Busu, P. E. Irving, "The role of residual stress and heat affected zone properties on fatigue crack propagation in friction stir welded 2024T351 aluminium joints", International Journal of Fatigue, Vol. 25, No. 1, pp. 77-88, 2003

[10] B. Bouchouicha, Contribution à l'étude de la déchirure ductile et de la propagation des fissures en fatigue dans les joints soudés, Thèse de doctorat, Djillali Liabes University of Sidi Bel Abbes, 2007

[11] C. Genevois, "Genesis of the microstructures during friction stir welding of aluminium alloys of the serie 2000 and 5000 and resulting mechanical behavior" (Genèse des microstructures lors du soudage par friction malaxage d'alliages d'aluminium de la série 2000 \& 5000 et comportement mécanique résultant), Thèse de doctorat, Institut National Polytechnique de Grenoble, 2004.

[12] M. Mazari, "Caractérisation mécanique des assemblages soudés par friction malaxage", WORKSHOP: Mécanique et Matériaux de la Microstructure à la structure: Approches Expérimentales \& Simulations Numériques, Mascara, 2010

[13] J. Souto Grela, E. B. Blanco Viana, D. Martinez, E. Piñeiro, "Numerical simulation in welding process: optimizing structures with sequence and inertial study", Matériaux \& Techniques, Vol. 100, pp. 317-326, 2012

[14] E. Feulvarch, Modélisation numérique du soudage par frictionmalaxage, Thèse de doctorat de l'Université de Saint Etienne, 2005

[15] M. Merzoug, Etude paramétrique du soudage par friction malaxage, Thèse de doctorat, Djillali Liabes University of Sidi Bel Abbes, 2011 